\title{
The paleobiogeographical significance of the Silurian and Devonian trilobites of Japan
}

\author{
Christopher P. Stocker ${ }^{1}$ () | Derek J. Siveter ${ }^{2}$ ( ) | Philip D. Lane ${ }^{3} \mid$ Mark Williams $^{1}$ (

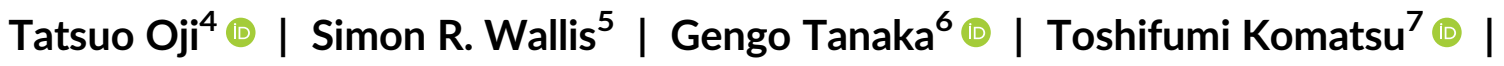 \\ David J. Siveter $^{1}$ () | Thijs R. A. Vandenbroucke ${ }^{8}$ (1)
}

${ }^{1}$ School of Geography, Geology and the Environment, University of Leicester, Leicester, LE1 7RH, UK

${ }^{2}$ Oxford University Museum of Natural History, Parks Road, Oxford, OX1 3PW, UK

${ }^{3}$ School of Earth Sciences, Keele University, Staffordshire, ST5 5BG, UK

${ }^{4}$ Nagoya University Museum, Nagoya University, Furo-cho, Chikusa-ku, Nagoya, 464-8601, Japan

${ }^{5}$ Department of Earth and Planetary Science, Graduate School of Science, The University of Tokyo, 7-3-1 Hongo, Bunkyo-ku, Tokyo, 113-0033, Japan

${ }^{6}$ Institute of Liberal Arts and Science, Kanazawa University, Kakuma-machi, Kanazawa City, 920-1192, Japan

${ }^{7}$ Faculty of advanced Science and Technology, Kumamoto University, 2-39-1, Kurokami, Chuo-ku, Kumamoto, 860-8555, Japan

${ }^{8}$ Department of Geology, Ghent University, Ghent, 9000, Belgium

Correspondence

Christopher P. Stocker

Email: cps10@leicester.ac.uk

Funding information

Leverhulme Trust, Grant/Award Number: International Network Grant IN-2014-025; Stapley Educational Trust Grant

\begin{abstract}
Six major groups of trilobites from the Silurian and Devonian of Japan are evaluated for their paleobiogeographical signature. Silurian illaenids and scutelluids show four generic-level and at least two species-level links with the Australian segment of the Gondwana paleocontinent; encrinurids also indicate two generic-level links with Australia and also the South China paleocontinent; whilst Devonian phacopids, and possibly proetids, suggest at least two generic-level links with the North China paleocontinent. These different patterns may reflect the fragmentary biostratigraphical record of Japanese trilobites, but they also appear to reflect paleoenvironmental parameters associated with lithofacies, and paleoecology. Thus, Japanese assemblages of proetids and phacopids occurring in deep-water clastic lithofacies have counterparts in similar settings in North China, and Japanese scutelluids and illaenids are strongly associated with shallow marine carbonate lithofacies that are similar to those of their occurrences in Australia. Japanese encrinurids occur in carbonate rocks indicative of shallow marine settings in the Kurosegawa Terrane, and they demonstrate a consistent paleobiogeographical affinity with Australia and South China. Larval ecology cannot be directly assessed for Japanese trilobite groups. However, proetids have consistently been shown to have planktonic protaspides, whereas illaenids, scutelluids, and encrinurids have benthic protaspides. Planktonic protaspides would have a greater propensity for distribution in ocean currents than benthic ones, and therefore may be of more limited paleobiogeographical utility. The combined data from the six different groups indicates that the complex paleobiogeographical patterns of the Japanese trilobite assemblages need to be interpreted with caution, and similarity of taxa does not necessarily denote paleogeographical proximity to other regions.
\end{abstract}

\section{KEYWORDS}

biogeography, biostratigraphy, Devonian, Japan, lithofacies, Silurian, trilobites

\section{1 | INTRODUCTION}

The Silurian and Devonian marine sedimentary successions of Japan comprise those of the South Kitakami Terrane (SKT) of north-eastern Honshu, the Hida Gaien Terrane (HGT) of central Honshu, and the Kurosegawa Terrane (KT), which extends from the Kii Peninsula in southwest Honshu to the islands of Shikoku and Kyushu (Figure 1). Strata in each of these terranes contain locally abundant fossil invertebrate faunas including brachiopods, cephalopods, ostracods and trilobites (see Williams, Wallis, Oji, \& Lane, 2014 for an overview of Japanese lower Paleozoic stratigraphy). Trilobites have been reported from each of these terranes (see Table 1), with the most diverse faunas reported from the Silurian Fukata Formation (approximately 32 species), and the Devonian Fukuji Formation and its lateral equivalent the Kamianama Formation (together $\sim 22$ species).

In this paper we focus on six groups of Japanese trilobites that have recently undergone taxonomic revision, and which are interpreted to have a range of paleoecologies. Recent revision of the Illaenidae and Scutelluidae (Holloway \& Lane, 1998, 2012, 2016) has demonstrated links between the trilobite faunas of Japan and Australia. It should be noted that the composition and delimitation of the families Illaenidae and Scutelluidae remain contentious, particularly so far as their effaced (illaenimorph) 


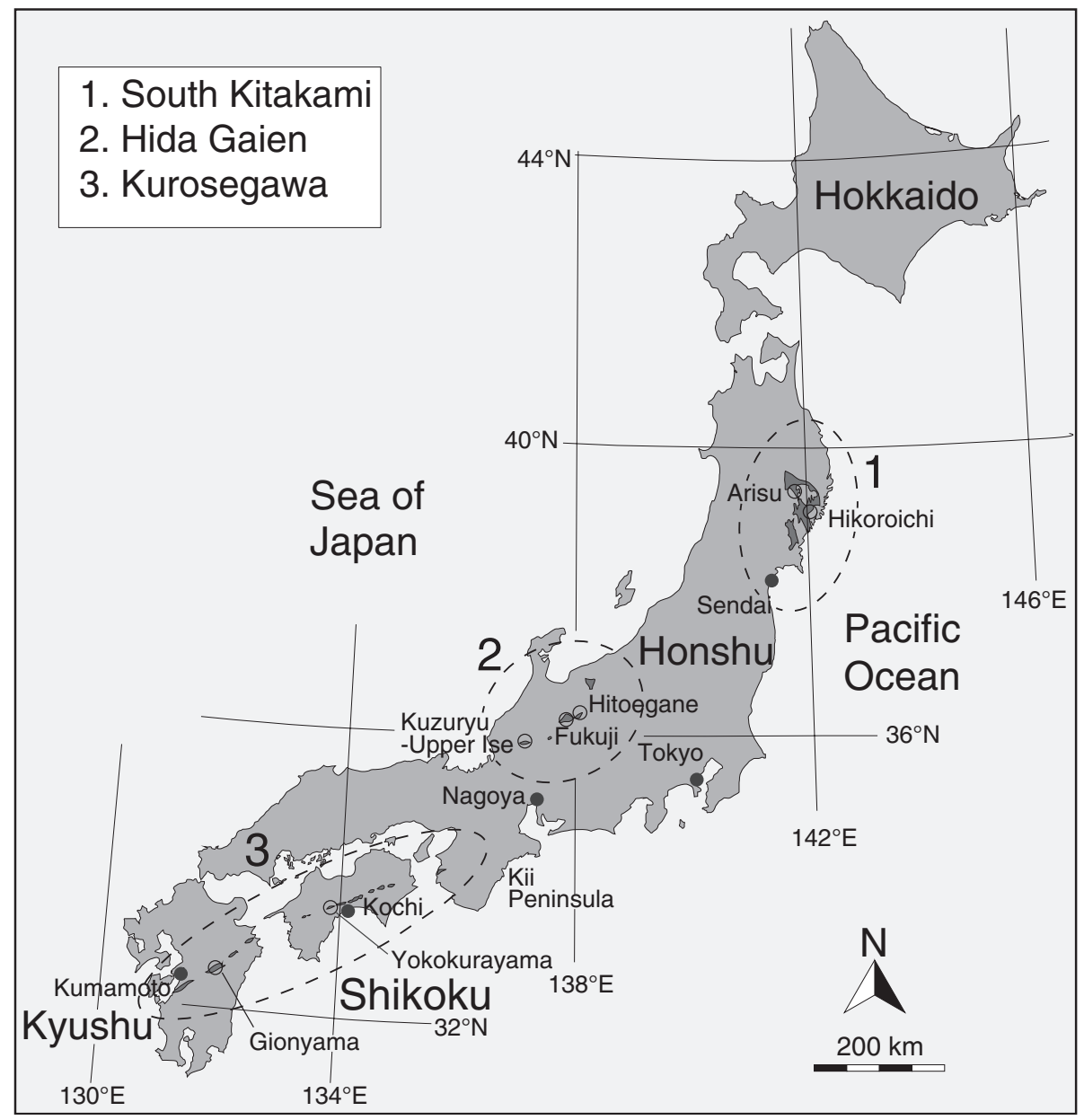

FIGURE 1 Position of the South Kitakami, Hida Gaien, and Kurosegawa terranes of Japan. The extent of the outcrop of each terrane is represented by areas with dark grey shading. Open circles denote areas containing trilobite-bearing rocks within each terrane, solid circles represent cities, and dashed lines highlight the three terranes

taxa are concerned (Holloway \& Lane, 1998, 2012, 2016; Lane \& Thomas, 1980; Whittington, 1999). Of the taxa belonging to those families dealt with in this paper, Bumastella, Rhaxeros and Lalax are assigned to the Illaenidae and Japonoscutellum, Illaenoscutellum, Kosovopeltis and Borenoria to the Scutelluidae, following Holloway and Lane (1998, 2012, 2016). Revision of Encrinuridae by Holloway (1994), Ramsköld (1986), Strusz (1980), and Zhang (1983) suggests links between Australia, Japan, and South China. Additionally, revision of the Phacopidae by Kaneko (1990, 2007), Stocker et al. (2018), and Zhou and Campbell (1990) has demonstrated links between the KT and SKT as well as with the North China paleocontinent. However, a recent review of the Proetidae and Aulacopleuridae of Japan (Stocker et al., 2018), considered both of these groups to be endemic at the species level, even between the Japanese terranes, though proetids suggested links with North China at the genus-level. These studies represent trilobite groups occurring in a range of lithofacies, and with a range of paleoecologies.

In this paper we evaluate the significance of the distribution patterns of Japanese trilobites from the Silurian and Devonian. We consider whether geography, lithofacies or ecology provides the strongest influence on the biogeographical patterns of the Japanese Silurian and Devonian trilobite faunas and assess whether biogeographical patterns changed over time.

\section{2 | BIOSTRATIGRAPHICAL RANGES OF THE SILURIAN AND DEVONIAN TRILOBITES OF JAPAN}

The trilobite material used in this study has been collected at different times, and by different authors over the past century (e.g. Kobayashi, 1988a, 1988b, 1988c; Kobayashi \& Hamada, 1974, 1976, 1977, 1985, 1987; see summary in Williams et al., 2014). As a result, piecing together the stratigraphical ranges of the different taxa relies on a detailed assessment of the trilobite literature, of geological maps of the various regions (e.g. see Stocker et al., 2018), and analysis of the most up-to-date literature on paleontological and radiometric dates for the region. Seven formations are trilobite-bearing (Figure 2). Here we summarize the data and approach we have used to assemble a composite trilobite biostratigraphy based on the six groups studied.

Graptolite biostratigraphy underpins the international correlation for rocks of Silurian and Early Devonian age, and provides a stratigraphical resolution in the Silurian of less than 1 million years for some biozones (Zalasiewicz et al., 2009). Palynological biozonations based on chitinozoans provide similar resolution (e.g. Steeman et al., 2016). However, the Japanese succession is so far devoid of graptolites, and biostratigraphically significant chitinozoans have only now been reported (Vandenbroucke et al., 2018). The biostratigraphical 


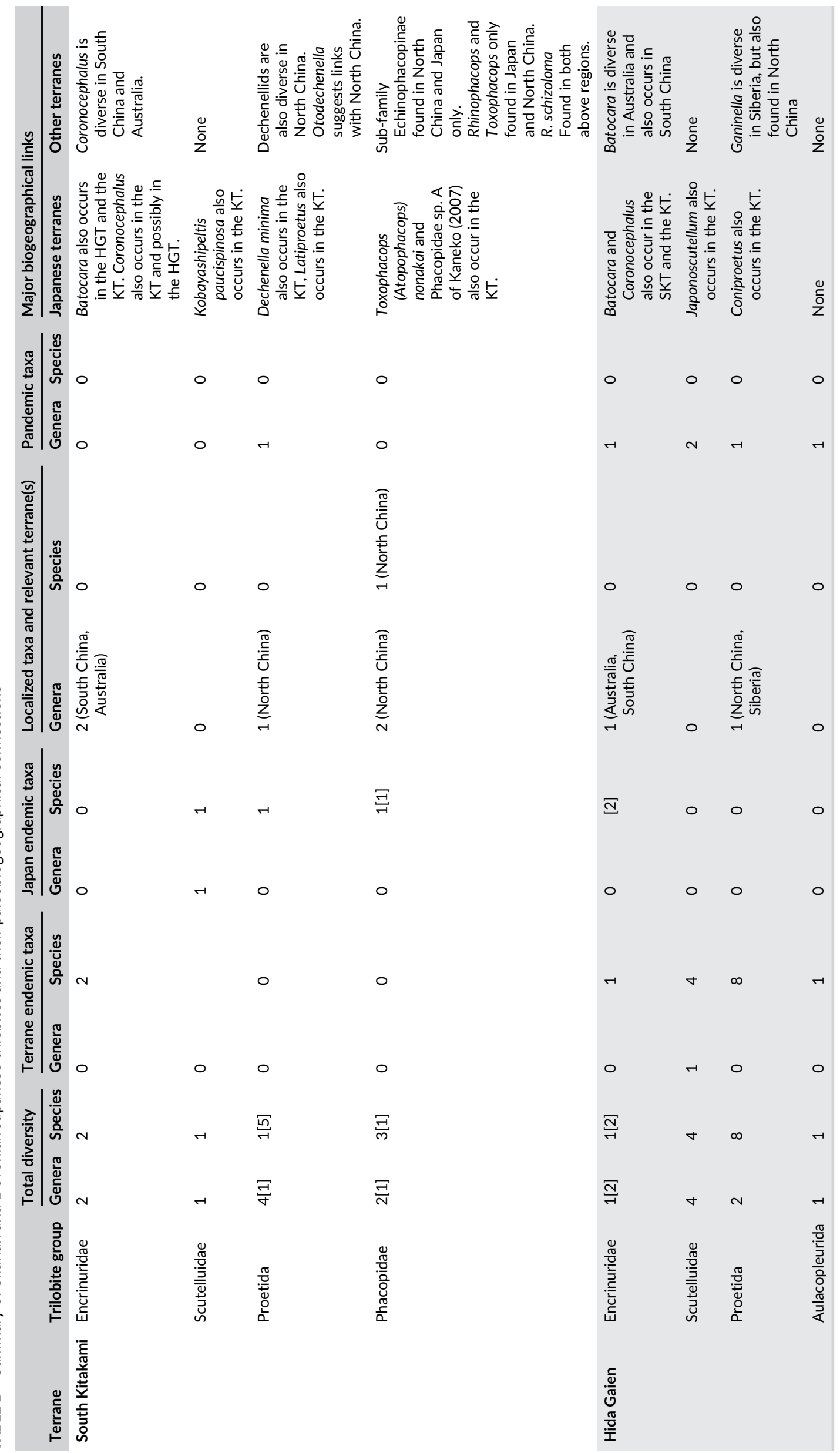




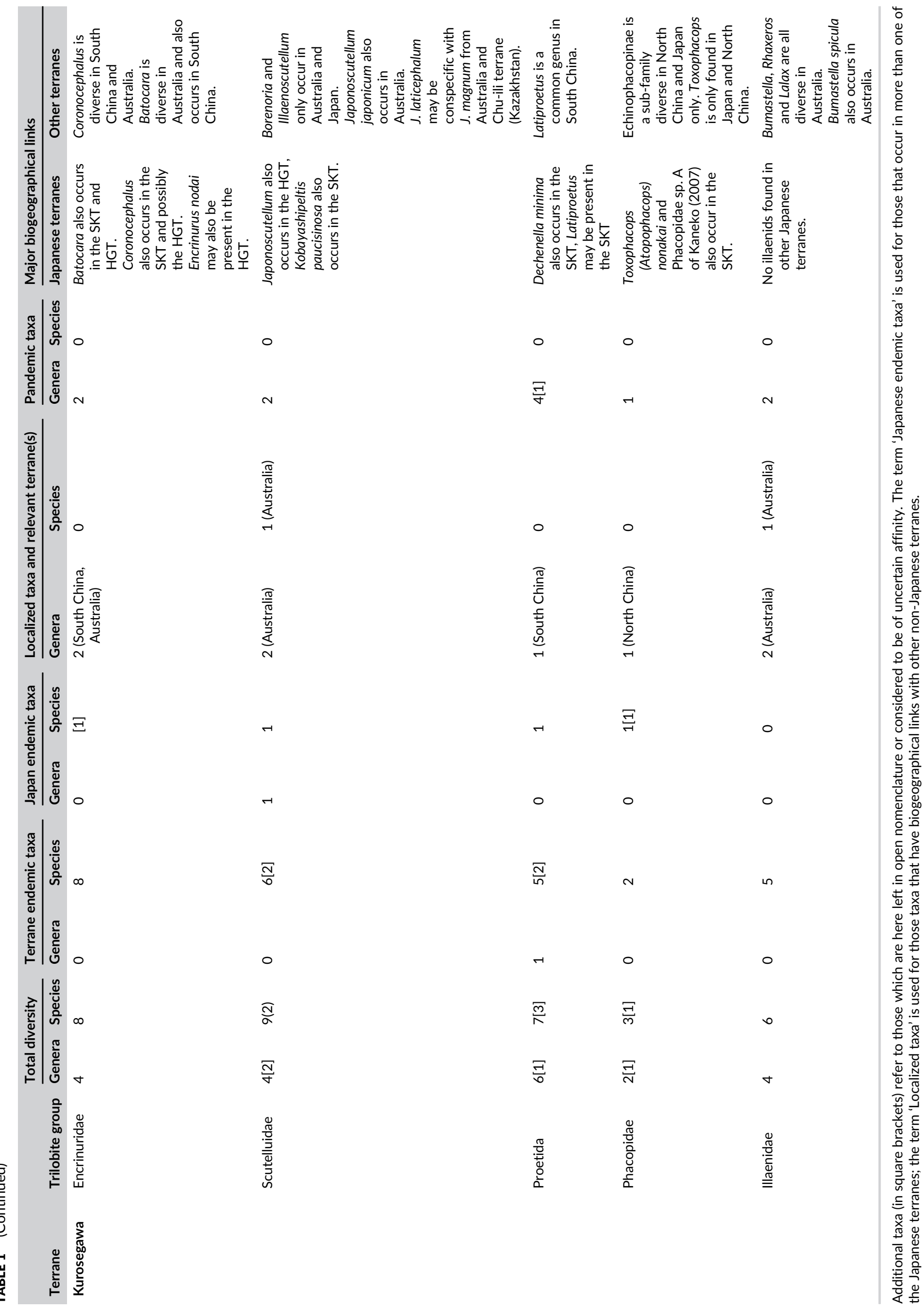




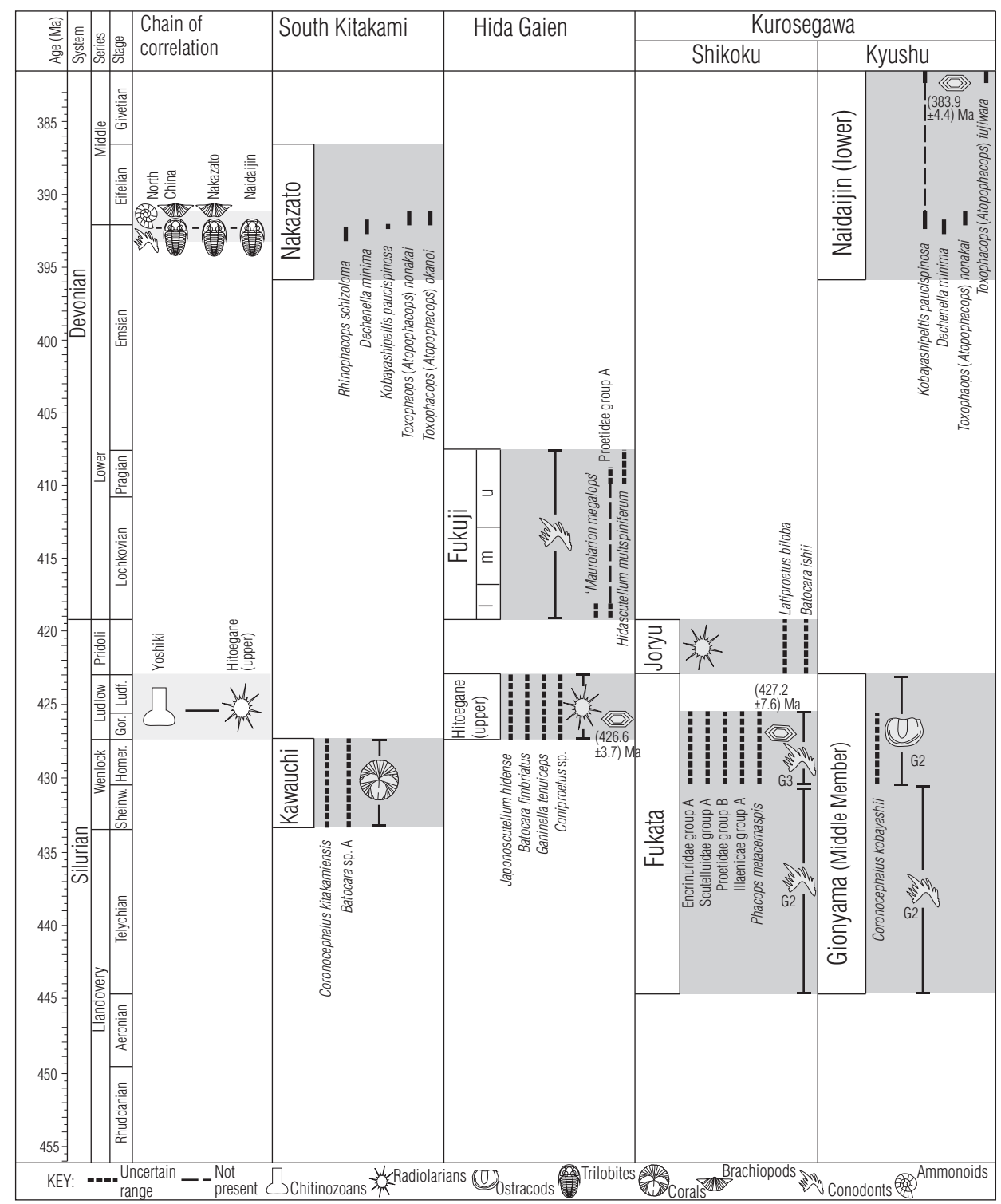

FIGURE 2 Temporal distribution of trilobites recorded across seven formations in the South Kitakami, Hida Gaien, and Kurosegawa terranes of Japan. Silurian stages are the Homerian, Sheinwoodian, Gorstian, and Ludfordian. Proetidae group A comprises the following species of the genus Ganinella (sensu Stocker et al., 2018): G. fukujiensis, G. oisensis, G. antijuba, G. angustus, G. latipolus, and G. longiconus. Proetidae group B comprises the following species: Interproetus sp. A, Eremiproetus? magnicerviculus, Eremiproetus? subcarinatus, Coniproetus subovalis, Gomiites granulatus, and Gomiites latiaxis. Encrinuridae group B comprises the following species: Batocara yokokurensis, Batocara mamelon, Encrinurus stenorhachis, Batocara tosensis, Encrinurus nodai, and Staurocephalus trichonin. Scutelluidae group A comprises the following species of the genus Japonoscutellum: J. japonicum, J. laticephalum, J. puteatum, J. angusticostatum, J. primigenium, as well as Kosovopeltis fungiformis, Kosovopeltis? geniculata, 'Japonoscutellum' tumidum (see Holloway \& Lane, 2012), Borenoria trinodosa and Illaenoscutellum platiceps. Illaenidae group A comprises the following species: Bumastella spicula, Rhaxeros subquadratus, Rhaxeros shinoharai, Lalax kattoi, Lalax sakoi, and Bumastus agmakros

assignment of different formations also depends on the interpretation of shelly faunas, or on the intermittent and serendipitous occurrence of biostratigraphically significant conodonts and radiolarians (e.g. Aitchison, Hada, Ireland, \& Yoshikura, 1996; Kurihara, 2003a, 2003b, 2004, 2007; Kurihara, Sato, \& Tazawa, 2005; Manchuk et al., 2013; Männik et al., 2018; Tsukada \& Koike, 1997; Umeda, 1998a, 1998b). The biostratigraphical and sometimes absolute ages of Japanese trilobites are here constrained by a combination of previously published microfossil biostratigraphy and zircon geochronology (Figure 2), enhanced by the new research on chitinozoans (Vandenbroucke et al., 2018), conodonts
(Männik et al., 2018) and ostracods (Siveter, Tanaka, Williams, \& Männik, 2018).

\section{3 | STRATIGRAPHY OF THE TRILOBITE- BEARING FORMATIONS OF JAPAN}

\section{1 | South Kitakami Terrane}

The Kawauchi Formation of the Hikoroichi area of Iwate Prefecture, Honshu, comprises strata of the Silurian Wenlock and Ludlow series based on biostratigraphical data from corals, conodonts and trilobites 
(Kato et al., 1980; Kido \& Sugiyama, 2011; Kobayashi, 1988c; Kobayashi \& Hamada, 1974). The 'Encrinurus bed' of the Kawauchi Formation sensu Sugiyama (1940) is considered to represent the lower to middle Ludlow (Kobayashi \& Hamada, 1976). Conodonts reported from this formation (Harashinai (1981) suggest the lower Sheinwoodian Stage of the Wenlock Series (Männik et al., 2018), though only a selected few taxa were illustrated by Harashinai (1981).

The N3 Member is a formal stratigraphic unit of the upper Nakazato Formation, also in the Hikoroichi area, is correlated by trilobites (Kaneko, 1990; Zhou \& Campbell, 1990), and gastropods (Pan \& Cook, 2003) with the Zhusileng Formation of Inner Mongolia, North China, where ammonoids and conodonts indicate the Emsian Stage. Brachiopods from another horizon within the N3 Member (Tazawa, 2002) correlate with the Eifelian Yikewusu Formation in the same region of North China, therefore effectively constraining the age of the N3 Member to Emsian-Eifelian by a chain of correlation. Kaneko (2007, p. 6, Figure 5) shows trilobites of the N3 Member straddling the boundary between the Emsian and Eifelian stages.

\subsection{1 | Hida Gaien Terrane}

The Hitoegane Limestone member is not a formal stratigraphic unit (see Williams et al. 2014) within the upper part of the Hitoegane Formation in the Hitoegane area of Gifu Prefecture, Honshu has yielded a diverse trilobite fauna suggesting either the middle or upper Ludlow Series (Kobayashi, 1988a, 1988b; Kobayashi \& Hamada, 1987), and a coral fauna indicative of the Ludlow (Niko, 2004). Radiolarians from tuffaceous clastic rocks of the upper Hitoegane Formation suggest an age range from the Ludlow to Early Devonian, but the relationship of the tuffaceous clastic rocks to the Hitoegane Limestone member is uncertain. Felsic tuffs in radiolarian-barren rocks intercalated between these radiolarian-bearing clastic strata provide a mean radiometric age of (426.6 \pm 3.7$) \mathrm{Ma}$ (Manchuk et al., 2013), which would indicate the Gorstian Age of the Ludlow Epoch.

New research on chitinozoans (Vandenbroucke et al., 2018) has refined the biostratigraphy of the Yoshiki Formation, also of the Hitoegane area, and established a biostratigraphical tie with the Ludlow Series (Gorstian or lower Ludfordian Stage) of the type Silurian in the Welsh Borderland. Approximate equivalence between the upper Hitoegane and Yoshiki formations is suggested by their similar radiolarian assemblages (Futobari solidus-Zadrappolus tenuis Zone), though this assemblage is longranging in the upper Silurian to lowest Devonian (Kurihara, 2007).

Silurian strata have been reported at the Hakubado locality, Izumi Village, Ohno County in the Kuzuryu Lake-Upper Ise river area of Fukui Prefecture (Ohno, Okazaki, \& Hirano, 1977) and Kobayashi and Hamada (1987) reported 'Encrinurus cf. similis' that might suggest a Wenlock age similar to the Fukata Formation, where E. similis was first described ( $E$. similis was synonymized with $E$. nodai from the same locality by Edgecombe \& Ramsköld, 1996).

The Devonian Fukuji Formation of the Fukuji area of Gifu Prefecture, Honshu, contains ostracods and conodonts that indicate Lower Devonian, Lochkovian to Emsian stages (Kuwano, 1987). The Kamianama Formation in the Kuzuryu Lake-Upper Ise river area of Fukui Prefecture is Lower to Middle Devonian based on radiolarians (Kurihara, 2003b, 2004; Niko \& Senzai, 2010), and the common occurrence of the trilobites Gravicalymene yamakoshii, Hidascutellum multispiniferum, and Crotalocephalina (Pilletopeltis) japonica suggests a correlation with the Fukuji Formation (Kobayashi \& Hamada, 1977).

\subsection{2 | Kurosegawa Terrane}

The Silurian Fukata Formation of the Yokokurayama Group, Kochi Prefecture, Shikoku has been biostratigraphically dated using conodonts, cephalopods and trilobites that collectively indicate the upper Wenlock or lower Ludlow (Kobayashi \& Hamada, 1985; Kuwano, 1976, 1980); however, see Männik et al. (2018) for uncertainties with the conodont data. The Silurian Joryu Formation of Ehime Prefecture, Shikoku has been dated as Pridoli based on radiolarians (Kurihara, 2009).

The Silurian Gionyama Formation of Miyazaki Prefecture, Kyushu was divided by Hamada (1959) into four lithostratigraphic and biostratigraphic units, termed 'Members G1 to G4' in ascending stratigraphic order. Subsequent work (e.g. Kido \& Sugiyama, 2007, 2011) has shown this subdivision to be untenable. Kido and Sugiyama (2007) divided the Gionyama Formation into Lower, Middle, and Upper members whose lithostratigraphical relationships to each other are complex and may in part be structural. The Silurian Middle Member of the Gionyama Formation (sensu Kido \& Sugiyama, 2011; equivalent to part of the 'G2' and 'G3' limestones of Hamada, 1959) has been dated from outcrop using conodonts (Männik et al., 2018), and these indicate the lower Wenlock (Sheinwoodian Stage). This horizon is from a black limestone conglomerate about $6 \mathrm{~m}$ below the trilobitebearing nodules evaluated herein (Figures 3 and 4). Ostracods in the same conglomerate suggest the Wenlock or lower Ludlow Series (Siveter et al., 2018). It should be noted, however, that these ostracods and conodonts are recovered from pebbles within a conglomerate, and therefore provide only a maximum age. Conodonts recovered from a loose boulder nearby, and likely also from the Middle Member, are indicative of the upper Llandovery (Männik et al., 2018).

The Lower Member of the Devonian Naidaijin Formation of Kumamoto Prefecture, Kyushu is dated via a chain of correlation with trilobites of the Nakazato Formation (see above). Detrital zircons from a sandstone bed $2 \mathrm{~m}$ above the trilobite-bearing horizon evaluated herein have yielded a radiometric age of $(383.9 \pm 4.4)$ Ma that is likely Givetian (late Mid-Devonian; Stocker et al., 2018).

\section{4 | JAPANESE PALEOGEOGRAPHY DURING THE EARLY AND MID-PALEOZOIC}

As highlighted by Williams et al. (2014) the biogeographical patterns of Japanese Ordovician to Devonian faunas are ambiguous, with links suggested with all of the major paleocontinents in the eastern periGondwanan region. Several competing paleogeographical reconstructions of this region for the early- and mid-Paleozoic exist, based on a combination of faunal and other data (see below for examples), but the position of Japan relative to the Gondwana, North China, or South China paleocontinents remains controversial with, for example, Cocks and Torsvik (2013) concluding that the paleontology of Japan is of limited biogeographical utility. They chose to place Japan as a unified island arc terrane off the margin of South China (Figure 5).

By contrast, Metcalfe (2006), who also noted that the position of Japan is at best speculative, suggested a position adjacent to eastern South China on the margin of the Australian part of Gondwana for the 

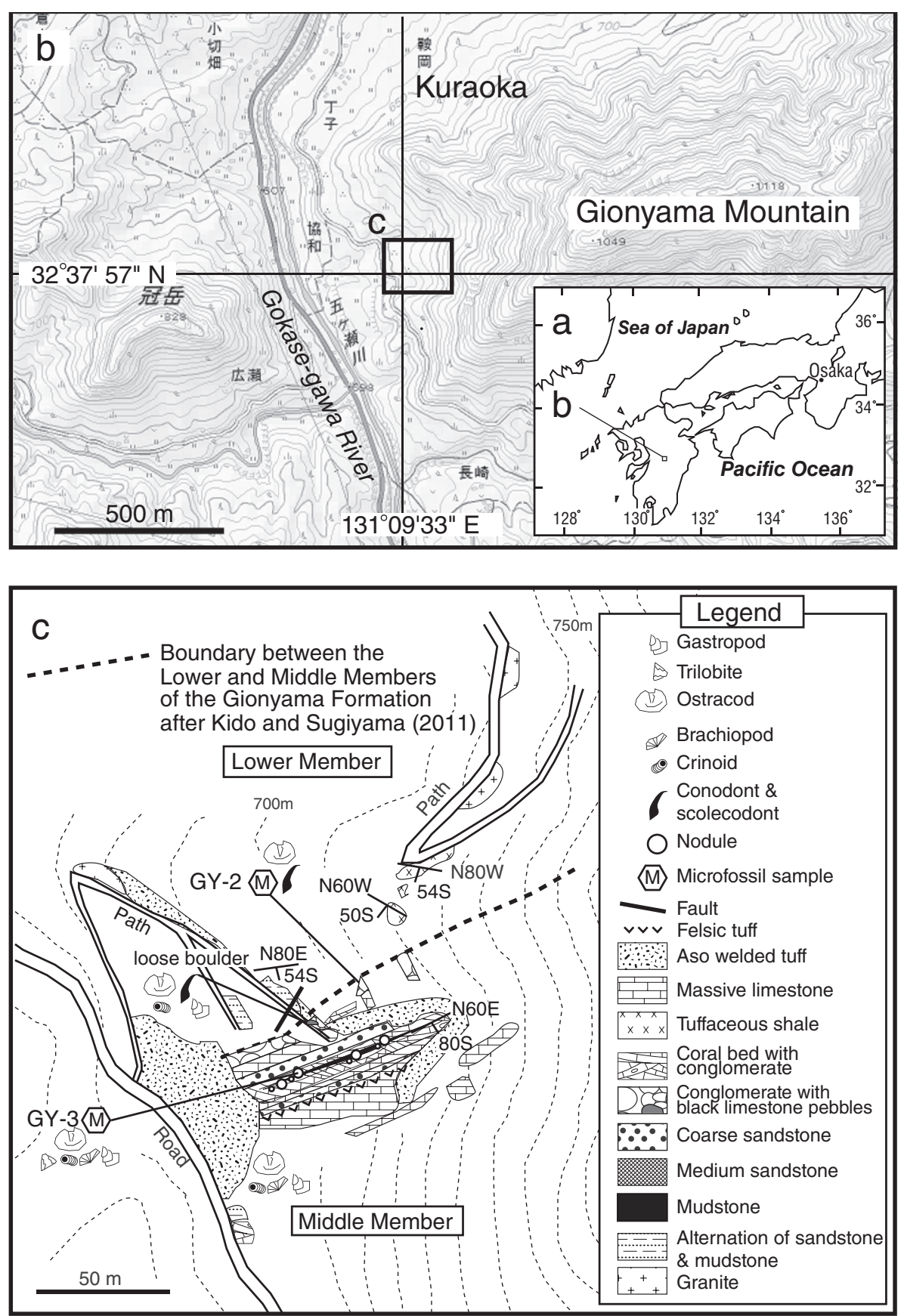

FIGURE 3 Locality map for biostratigraphically diagnostic conodont samples at Gionyama, Kuraoka, Miyazaki Prefecture, central Kyushu Island. In map ' $c$ ', the position of the scolecodont/conodont/ostracod-bearing black limestone GY-2, sampled from outcrop within the Middle Member (sensu Kido \& Sugiyama, 2011) is marked, as is the loose boulder (GY-1). Sample GY-3 of this figure contains ostracods described by Siveter et al. (2018), but no conodonts. For the stratigraphical position of samples GY-2 and GY-3 see Figure 4

KT (Hisada, Arai, \& Negoro, 1994; Saito, 1992), and an origin along the North China paleocontinent for the SKT (Yoshida \& Machiyama, 2004). Metcalfe (2006, p. 27, Table 1) summarized the multidisciplinary data that his reconstructions were based on, which included (but were not limited to) data from paleobiogeographic constraints, paleoclimatology, paleomagnetic data, detrital zircon provenance, and the positions of volcanic intrusions. In the reconstruction presented by Metcalfe (2006, p. 39, Figure 6) South China is over the paleo-equator, with Tarim to the northnorthwest, and North China to the northwest of Tarim. This is in contrast to Cocks and Torsvik (2013, p. 57, Figure 11) who presented North China far to the west of South China, and Tarim even further west. In contrast,
Tazawa (2002) suggested an origin along the northern or eastern margin of the North China paleocontinent for all three of the Japanese terranes discussed here (see also Tazawa, 1993, 2000, 2001, 2004).

\section{5 | PALEOBIOGEOGRAPHICAL AFFINITY OF JAPANESE SILURIAN AND DEVONIAN TRILOBITES}

The diversity of trilobites of each of the six groups studied here, along with their paleobiogeographical affinities, is represented in Table 1. 


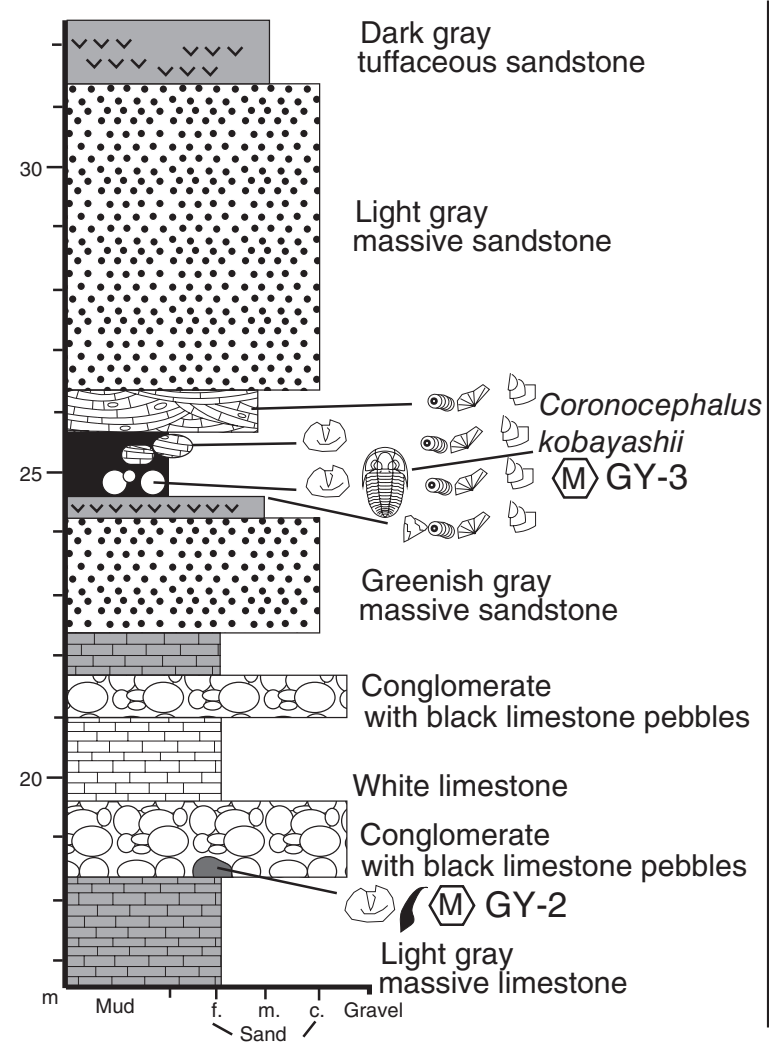

\begin{tabular}{|c|c|}
\hline & Leaend \\
\hline 47 & Gastropod \\
\hline & Trilobite \\
\hline (i) & Ostracod \\
\hline$\nabla$ & Brachiopod \\
\hline ब & Crinoid \\
\hline & $\begin{array}{l}\text { Conodont \& } \\
\text { scolecodont }\end{array}$ \\
\hline & Coral conglomerate \\
\hline & Nodule \\
\hline$\langle\mathrm{M}$ & Microfossil sample \\
\hline マレレ & Felsic tuff \\
\hline 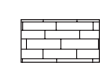 & Massive limestone \\
\hline 無竞 & $\begin{array}{l}\text { Coral bed with } \\
\text { conglomerate }\end{array}$ \\
\hline$b$ & $\begin{array}{l}\text { Conglomerate with } \\
\text { black limestone pebbles }\end{array}$ \\
\hline$\because \because \because \because$ & Coarse sandstone \\
\hline & Fine sandstone \\
\hline & Mudstone \\
\hline
\end{tabular}

FIGURE 4 Stratigraphical column showing the position of the biostratigraphically diagnostic conodont bearing sample GY-2 see (Männik et al. 2018) from outcrop at Gionyama (see Figures 2 and 3), in relation to the trilobite species Coronocephalus kobayashii. Sample GY-2 also yields scolecodonts, and ostracods (see Vandenbroucke et al., 2018; Siveter et al., 2018). A younger conglomeratic horizon (GY-3) yields ostracods but no conodonts. The abbreviations 'f.', 'm.', and 'c.' refer to fine, medium, and coarse grained sandstone, respectively

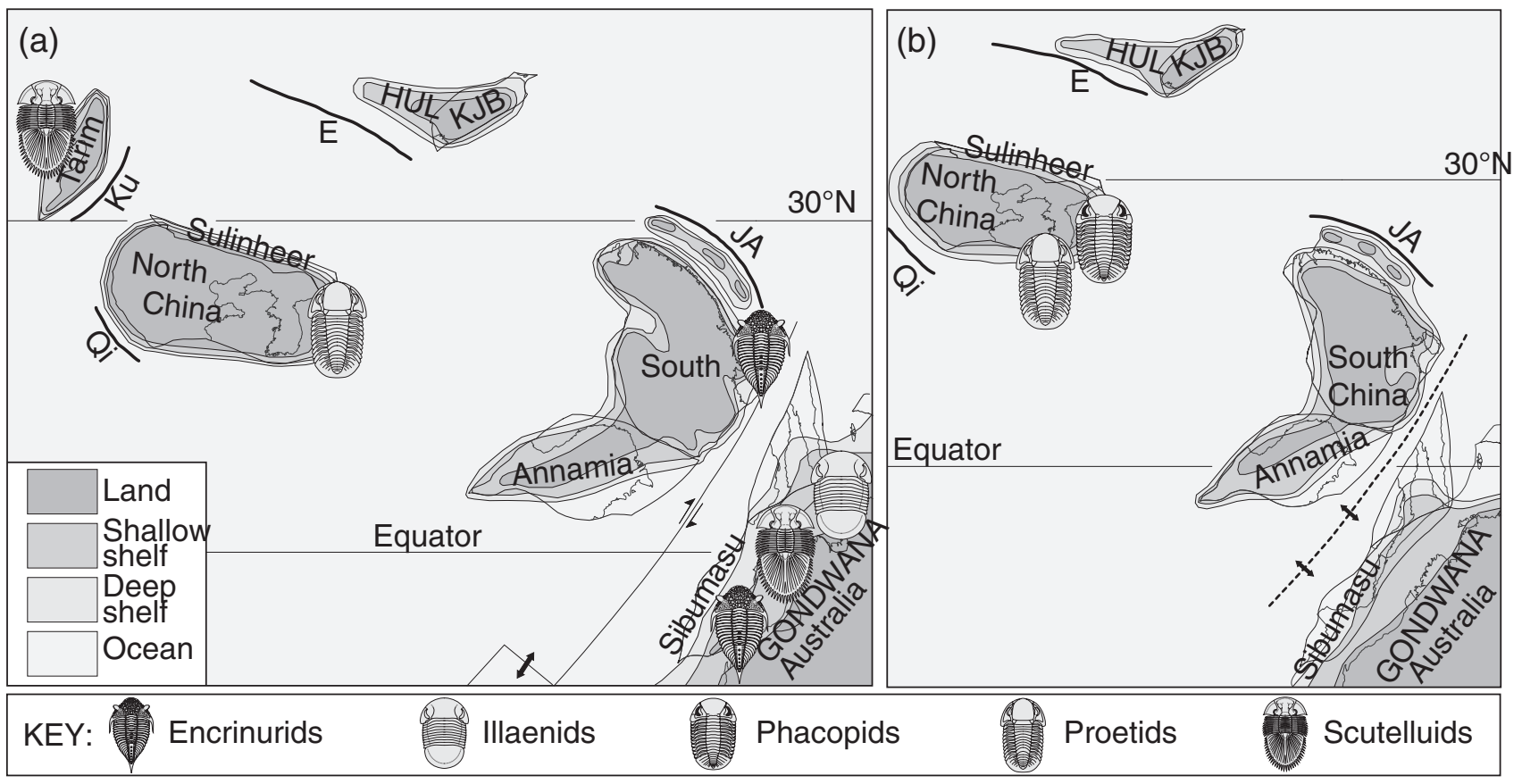

FIGURE 5 Paleogeographical position of the Japanese Arc (JA) during the late Silurian and Early Devonian, following the reconstruction of Cocks and Torsvik (2013), with trilobite groups that show links to different regions. (a) Late Silurian. (b) Devonian. Major plate margins are represented by the following lines: Dashed line with diverging arrows for a spreading margin, solid line with opposing half arrows for a strike-slip margin, and bold solid line for subduction zone. The following abbreviations apply: E, Enshoo Arc Trilobite symbols courtesy of Dr. Sam Gon III; HUL, Huutag Uul-Songliao; KJB, Khanka-Jiamusu-Bureya; Ku, arcs now in the Kunlun Terrane; Qi, arcs now in the Qaidam-Qilian Terrane 

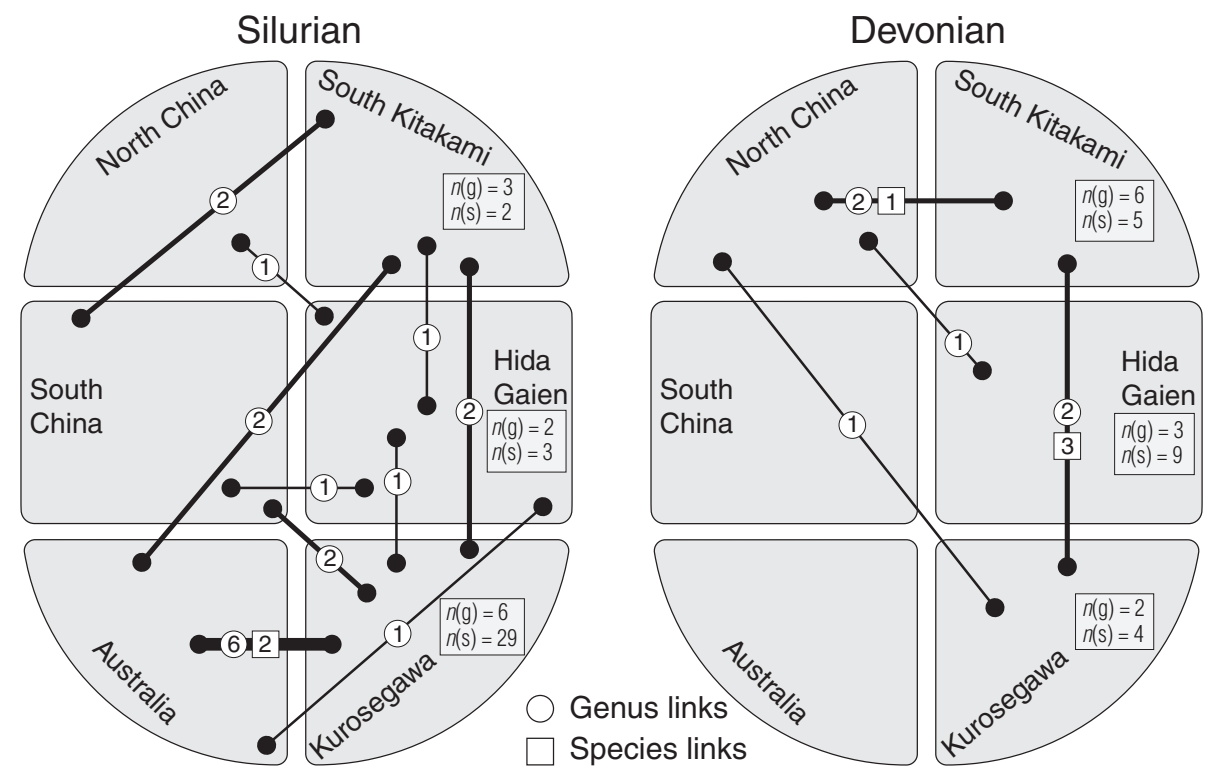

FIGURE 6 Paleobiogeographical connections of trilobite genera and species between the three Japanese terranes and with other regions. Coarser lines equate to a greater number of generic links. Pandemic taxa have been excluded from the analysis, and the total number of taxa analysed is given as ' $n(g)$ ' and ' $n(s)$ ' for genera and species respectively. Sizes and positions of terranes are schematic, and not to scale

Figure 6 summarizes the paleobiogeographical links for the Silurian and Devonian between each of the Japanese terranes and other regions, and Figure 7 illustrates a representative sample of Silurian and Devonian trilobites from the three terranes.

\section{1 | Silurian links with the Australian segment of East Gondwana}

Illaenidae and Scutelluidae (Holloway \& Lane, 1998, 2012) from the Silurian Fukata Formation of the KT show four species links, through Bumastella spicula, Borenoria trinodosa, Japonoscutellum japonicum and J. magnum (Table 1), with the Molong and Mirabooka Formations of the Australian Benambra Terrane. The illaenids Bumastella and Rhaxeros, and scutelluid genera Borenoria and Illaenoscutellum are also only found in Australia and the KT of Japan.

Similarities between Silurian encrinurids of the Benambra Terrane of Australia and the KT and HGT of Japan were suggested by Strusz (1980), who included the Japanese Encrinurus species E. ishii, E. mamelon, E. tosensis, and E. yokokurensis from the $\mathrm{KT}$, and E. fimbriatus from the HGT, in the 'mitchelli-Plexus', species of which were subsequently assigned to Batocara (see Edgecombe \& Ramsköld, 1992; Holloway, 1994). Another species from the SKT has been assigned to Batocara as part of our study. The encrinurid Batocara is common in Australia, and also occurs in the Fukata Formation of the $\mathrm{KT}$, and the upper Hitoegane Formation of the HGT. Species of Coronocephalus occur in the Benambra Terrane of Australia and the Silurian Gionyama and Kawauchi Formations of the KT and SKT, respectively; the genus may also occur in the upper Hitoegane Formation of the HGT (see below).

\section{2 | Silurian links with South China}

As noted above, species of the encrinurid Batocara are common in Australia, but also occur in the South China paleocontinent as well as the
Fukata Formation of the KT, the upper Hitoegane Formation of the HGT, and the Kawauchi Formation of the SKT. There are no species-level links between these terranes, however. Species of Coronocephalus are diverse throughout the South China paleocontinent, and also occur in Australia and the Gionyama and Kawauchi Formations of the KT and SKT, respectively. Again, there are no species-level links between any of these terranes.

\section{3 | Silurian links with North China}

Proetids from the upper Hitoegane Formation in the HGT suggest generic links with North China. Ganinella tenuiceps is found in the upper Hitoegane Formation. There are several Silurian species of Ganinella in Siberia, and the genus has representatives in North China. However, Ganinella may be a biogeographically widespread genus (see below).

\subsection{Devonian links with North China}

At least two species of the proetid genus Ganinella, G. fukujiensis and G. oisensis, occur coevally in the Fukuji and Kamianama Formations of the HGT. Ganinella is a common Siberian genus, which also occurs in North China, but it may be widespread, with closely related genera such as Lacunoporaspis having a global distribution; relationships between these closely related genera, however, are difficult to resolve at present, and require a detailed phylogenetic analysis (see Stocker et al., 2018).

Devonian phacopids of the KT and SKT of Japan (Kaneko, 1990, 2007; Stocker et al., 2018) show strong generic links, and one species link with North China (Kaneko, 1990, 2007; Zhou \& Campbell, 1990). The sub-family Echinophacopinae, including Toxophacops and Rhinophacops, are only found in the Zhusilenghaierhan region of Inner Mongolia, North China, and the KT and SKT of Japan. The species Rhinophacops schizoloma is also only found in the SKT and North China. 
The Devonian proetids from the Nakazato Formation also indicate generic links with North China, with, Dechenella, Otodechenella, and Paradechenella occurring in both regions (Kaneko, 2007), although
Dechenella has a global distribution. Otodechenella is only found in the Zhusilenghaierhan region of Inner Mongolia, North China, and the SKT of Japan.
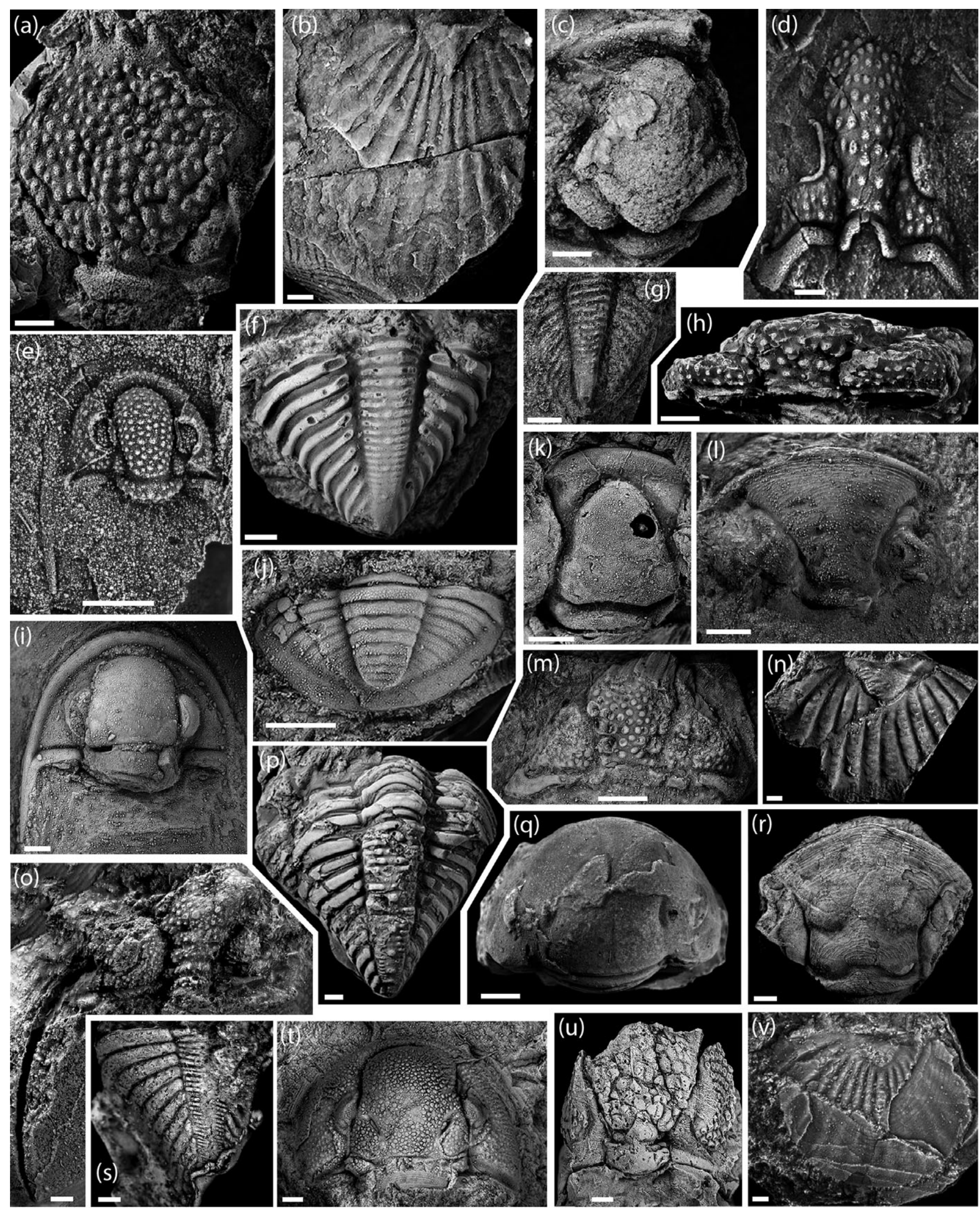

FIGURE 7 Legend on next page. 


\section{5 | Intra-Japanese terrane links}

In the Silurian there are no species links between the three terranes (Figure 6). 'Encrinurus cf. similis', reported by Kobayashi and Hamada (1987) from the Silurian of Hakubado in the HGT, is too poorly preserved to compare with material of Encrinurus from the KT. The encrinurid genus Batocara occurs in all three Japanese terranes, but is more species diverse in the Fukata Formation of the $\mathrm{KT}$, and the encrinurid genus Coronocephalus occurs in the Kawauchi Formation of the SKT, the Gionyama Formation of the KT, and possibly the upper Hitoegane Formation of the HGT (Encrinurus cf. kitakamiensis of Kobayashi and Hamada (1987)). The scutelluid genus Japonoscutellum occurs in the Fukata Formation of the KT and the upper Hitoegane Formation of the HGT. The proetid genus Coniproetus also occurs in the Fukata and upper Hitoegane formations, but it is a globally distributed taxon. Illaenids only occur in the KT.

In the Middle Devonian phacopids and proetids of the Naidaijin Formation of the KT and the Nakazato Formation of the SKT of Japan (Kaneko, 1990, 2007; Stocker et al., 2018) show species-level links between these two terranes; the phacopid species Toxophacops (Atopophacops) nonakai, the proetid Dechenella minima, and the scutelluid Kobayashipeltis paucispinosa also occur in the Naidaijin and Nakazato Formations (Kaneko, 2007) of the KT and SKT terrane, respectively. Kobayashipeltis is endemic to these two Japanese terranes.

\section{6 | Summary}

In a general sense then, the Silurian trilobites of all three terranes suggest closest links with the South China and East Gondwanan regions (Figure 6; Table 1). Ganinella in the HGT is the only common link with North China during the Silurian. By contrast, Devonian trilobites consistently show strongest affinities with those of North China, including material from all three Japanese terranes examined here.

In terms of intra-Japanese terrane connections, in the Silurian there are no species-level biogeographical links between the three terranes (Figure 6). The strongest generic links between all three terranes are represented by the encrinurids Batocara and Coronocephalus, both of which also occur in South China and Australia.
In the Devonian there are strong specific and generic links between the SKT and KT (Figure 6), but similar links with the HGT are only suggested by limited material of a calymenid species, Nipponocalymene hamadai which occurs in the Rosse Formation, as well as the Nakazato and Naidaijin Formations (Kaneko, 2007); the trilobite fauna from the Fukuji Formation (HGT) is very different from that of the other two terranes.

Some groups, e.g. the proetids from the Fukata Formation of the $\mathrm{KT}$, appear to be more endemic than other trilobite groups with which they co-occur, such as scutelluids, illaenids and encrinurids. The Devonian proetids from the upper Hitoegane and Fukuji Formations of the HGT appear to indicate generic links with North China and Siberia, whereas other co-occurring trilobite groups (Calymenidae, Cheiruridae, Lichida) have demonstrated generic links with the South China paleocontinent (Kaneko, 2007; Wang, Boucot, Rong, \& Yang, 1987) and in the case of Lichida also with Australia (Sherwin \& Meakin, 2010). This suggests that factors in addition to paleogeography are at play. In the following section, we examine the significance of lithofacies relationships and ecology in this context.

\section{6 | PALEOENVIRONMENTAL AND PALEOECOLOGICAL CONTROLS ON TRILOBITE DISTRIBUTION}

\section{1 | Lithofacies}

The Silurian and Early Devonian trilobite-bearing lithofacies of Japan are dominated by shallow marine carbonate rocks, but in the Devonian the trilobite lithofacies are characteristically deeper-water siliciclastics (see Figure 8). The taxa from all three Japanese terranes in the Silurian suggest links with Australia and South China, where carbonate lithofacies contain similar faunas, whereas in the Devonian the Japanese trilobites show clear links with North China. Given the change of predominant lithofacies between the Silurian and Devonian (carbonate to siliciclastic), this may suggest some degree of environmental control on trilobite distribution that has also been noted for other invertebrate faunas of Japan (Williams et al., 2014). Thomas (1979) suggested that

FIGURE 7 Representative Silurian and Devonian Japanese trilobites: (a-d,g), South Kitakami terrane; (e,f,j-l,n) Hida Gaien terrane; (i,m,o-v) Kurosegawa terrane. (a) Rhinophacops cf. schizoloma Kaneko, 1990 cephalon (OCM.G000588). (b) Kobayashipeltis paucispinosa (Okubo, 1951), holotype pygidium (PA08001). (c) Dechenella minima Okubo, 1951, holotype cranidium (PA8006). (d) Batocara sp. A, cranidium (OCM.G000638). (e) 'Maurotarion megalops' (Kobayashi \& Hamada, 1977), juvenile cephalon (OUMNHDY.15). (f) Batocara fimbriatus Kobayashi \& Hamada, 1974), pygidium (PA18108). (g) Dechenella cf. minima, pygidium (OCM.G000578). (h) Batocara sp., cranidium (OCM.G00627). (i) Interproetus sp. A, cephalon (SGMX1-11). (j) Ganinella oisensis (Kobayashi \& Hamada, 1977), pygidium (NUM-Fa218). (k) Ganinella fukujiensis (Kobayashi \& Hamada, 1977), paratype cranidium (PA8963). (I) Japonoscutellum hidense (Kobayashi \& Hamada, 1987), holotype cranidium (PA18095). (m) Batocara yokokurensis (Kobayashi \& Hamada, 1974), holotype cranidium (KPFM618). (n) Japonoscutellum hidense, pygidium (PA18096). (o) Coronocephalus kobayashii, holotype cranidium (PA07280). (p) Batocara yokokurensis, thoracopygon (SGMX1-15). (q) Bumastella spicula (Kobayashi \& Hamada, 1974), juvenile cephalothorax (KPFM15155). (r) Japonoscutellum japonicum Kobayashi \& Hamada, 1974, holotype cranidium (PA07353).

(s) Coronocephalus kobayashii, paratype pygidium (PA7294). (t) Gomiites latiaxis (Kobayashi \& Hamada, 1986), holotype cephalon (PA18078). (u) Toxophacops (Atopophacops) fujiwara, composite image of part and counterpart of topotype cephalon (OUMNH DY4a,b). (v) J. japonicum, paratype pygidium (PA7354). (a-c,g) from the Devonian (Emsian to Eifelian) Nakazato Formation, Hikoroichi, Iwate Prefecture, Honshu; (d,h) from the Silurian (Wenlock) Kawauchi Formation Hikoroichi, Iwate Prefecture, Honshu Island; (e,j,k) are from the Devonian (Lochkovian to Emsian) Fukuji Formation, Okuhida-onsen-gou, Takayama City, Gifu Prefecture, Honshu Island; (f,l,n) from the Silurian (Ludlow) upper Hitoegane Formation, Kamitakara-mura, Yoshiki-gun, Gifu Prefecture, Honshu Island; (u) from the Devonian (Emsian to Givetian) Lower Member of the Naidaijin Formation, Shimomashiki District, Kumamoto Prefecture, central Kyushu Island, Japan; (o,s) are from the Silurian (Wenlock, Sheinwoodian) Gionyama Formation, Kuraoka, Miyazaki Prefecture, central Kyushu Island; (i,m,p,q,r,t,v) from the Silurian Fukata Formation of Yokokurayama, Ochi, Kochi Prefecture, Shikoku Island. All specimens are in dorsal view. Scale bars represent $2 \mathrm{~mm}$ 


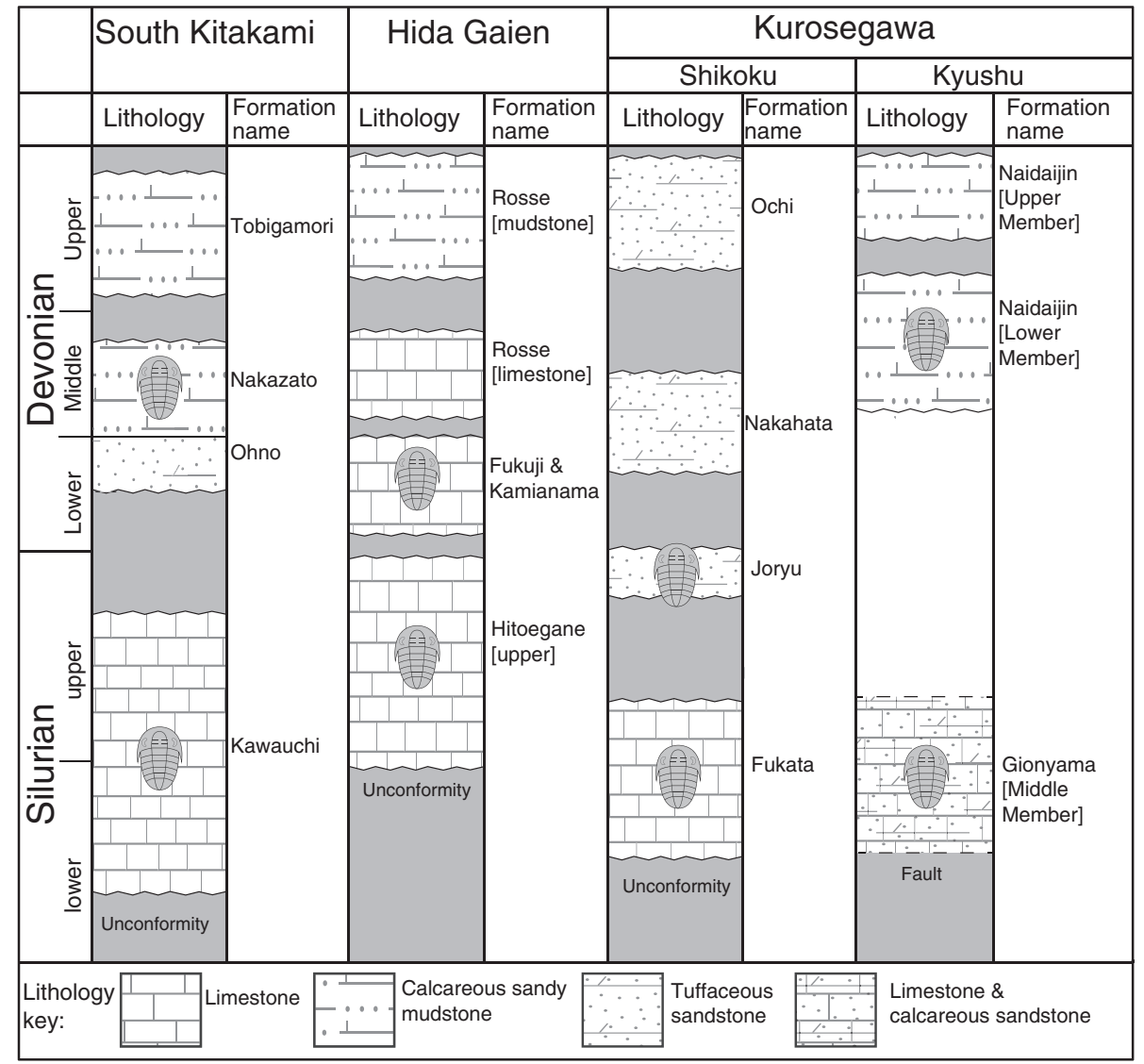

FIGURE 8 Lithology of each of the Japanese trilobite-bearing formations across the three terranes. Grey areas of the columns indicate uncertainty or gaps in the stratigraphy

in the Wenlock of the UK, trilobite distribution reflects original environmental variables, so that there is a close but not invariable correlation between the distribution of trilobite taxa and lithofacies. Some of the trilobite groups that occur in the Japanese formations, including some Proetida and Phacopidae, occur in both carbonate and clastic lithofacies. This is the case for the proetids of the carbonate dominated Fukuji and Kamianama Formations in the HGT and those in the siliciclastic dominated Nakazato Formation of the SKT, which nevertheless show consistent generic links with North China.

\section{2 | Paleoecology}

Of the Japanese trilobite groups discussed here, the majority are interpreted to be predators/scavengers (Fortey \& Owens, 1999), with only one, the proetids, being considered as detritivores (Fortey \& Owens, 1999)

The Japanese scutelluids are in general somewhat restricted biogeographically, but with one species with a very broad distribution, Japonoscutellum magnum, which occurs in Australia, possibly Japan (Holloway and Lane (2012) suggested that J. laticephalum may be conspecific with magnum), and Kazakhstan. Illaenids are very restricted, with two genera and one species restricted to Australia and the KT of Japan. Japanese proetids are endemic to each terrane at the species-level, but some genera are globally distributed (Coniproetus and Interproetus for example), others have wide distributions across Asia and to Siberia (Ganinella for example), and some are more restricted to South China and Australia (Latiproetus); there is only one endemic genus, Gomiites. Suggestions of other behavior relating to lifestyle have been offered for some of these groups. For example, scutelluids with flat exoskeletal morphologies have been interpreted as capable of swimming, using their large paddle-like pygidia (Chatterton, 1971; Feist \& Lerosey-Aubril, 2008; Selwood, 1966), whereas some illaenids have been interpreted as burrowing into sediment. Proetids, however, have been interpreted in some cases as inhabiting sheltered cavities in the surface of reefs (Hughes \& Thomas, 2011). These interpretations suggest that autecology has a variable effect on biogeography, but perhaps even more important is larval-stage ecology.

The majority of trilobite groups have been found to possess a calcified larval stage known as a protaspid. Protaspides have been shown to occupy either planktonic or benthic lifestyles of different duration (Chatterton \& Speyer, 1989; Speyer \& Chatterton, 1989). Groups with planktonic protaspides include proetids and phacopids, whereas encrinurids, scutelluids, and illaenids have been determined to have benthic protaspides. It is assumed that planktonic protaspides would be capable of more widespread distribution, and therefore such groups would be more geographically disparate than those with benthic protaspides.

\section{7 | CONCLUSIONS}

There are stronger paleobiogeographical links between the trilobites of the three Japanese terranes in the Devonian than in the Silurian. In 
the Silurian, scutelluids and illaenids of the KT show strong overall generic- and species-level links with the Australian segment of eastern Gondwana, and encrinurids from all three Japanese terranes indicate generic-level links with the South China paleocontinent and the Australian segment of eastern Gondwana. A single proetid genus from the HGT suggests links with the North China paleocontinent, although this genus may in fact be pandemic. In the Devonian, phacopids indicate strong overall generic-level links between the KT and SKT and the North China paleocontinent, with a single species-level link between the Nakazato Formation of Iwate Prefecture and the Zhusileng Formation of Inner Mongolia. Proetids from the Early Devonian of the HGT and the Middle Devonian of the SKT, both suggest generic-level links with the North China paleocontinent. Of those genera and species with links to North China, the vast majority are from deeper-water siliciclastic facies, whereas genera with links to Australia and South China are all from shallow water carbonate facies. Scutelluids and illaenids are strongly restricted to limestone facies, and this may have an influence on links with Australia, where they occur in similar limestone facies. These data suggest that in the Silurian and Devonian of Japan, environmental setting may have exerted a strong influence on the biogeographical signal of trilobites, and thus inferences about paleogeography need to be made with caution.

\section{ACKNOWLEDGEMENTS}

Mark Williams thanks The Leverhulme Trust International Network project IN-2014-025 'Assembling the Early Palaeozoic Terranes of Japan' for funding this research. Chris Stocker gratefully acknowledges a grant from the Stapley Trust for funding his PhD research. We thank the curators of Tokyo University Museum, Kyoto University Museum, Yokokurayama National Forest Museum, Sakawa Geology Museum, Iwate Prefectural Museum and Ofunato City Museum, for help and access to specimens. Dr. Sam Gon III is thanked for the use of his trilobite line drawings. We thank Alan Thomas and an anonymous reviewer for detailed and constructive comments on the manuscript.

\section{Declaration of conflicting interest}

The authors declare that they have no competing interest.

\section{Authors' contributions}

MW devised the 'Assembling the Early Palaeozoic terranes of Japan' project. CPS, DJS, PDL and MW wrote the manuscript with input from all authors. CPS, TO and GT undertook fieldwork.

\section{ORCID}

Christopher P. Stocker (D) https://orcid.org/0000-0001-5553-7006 Derek J. Siveter (D) https://orcid.org/0000-0002-5305-2192 Mark Williams (ID https://orcid.org/0000-0002-7987-6069 Tatsuo Oji (D) https://orcid.org/0000-0002-1034-1111 Gengo Tanaka (D) https://orcid.org/0000-0002-2975-6675 Toshifumi Komatsu (D) https://orcid.org/0000-0003-0190-3220 David J. Siveter (D) https://orcid.org/0000-0002-1716-5819

\section{REFERENCES}

Aitchison, J. C., Hada, S., Ireland, T., \& Yoshikura, S. (1996). Ages of Silurian radiolarians from the Kurosegawa terrane, Southwest Japan constrained by U/Pb SHRIMP data. Journal of Southeast Asian Earth Sciences, 14(1), 53-70. https://doi.org/10.1016/S0743-9547(96)00045-1

Chatterton, B. D. E. (1971). Taxonomy and ontogeny of Siluro-Devonian trilobites from near Yass, New South Wales. Palaeontographica, Abteilung $A, 137,1-108$.

Chatterton, B. D. E., \& Speyer, S. E. (1989). Larval ecology, life history strategies, and patterns of extinction and survivorship among Ordovician trilobites. Paleobiology, 15, 118-132. https://doi.org/10.1017/ s0094837300009313

Cocks, L. R. M., \& Torsvik, T. H. (2013). The dynamic evolution of the Palaeozoic geography of eastern Asia. Earth-Science Reviews, 117, 40-79. https://doi.org/10.1016/j.earscirev.2012.12.001

Edgecombe, G. D., \& Ramsköld, L. (1992). The Silurian encrinurine trilobite Pacificurus: New species from North America. Journal of Paleontology, 66, 255-262. https://doi.org/10.1017/s002233600003376x

Edgecombe, G. D., \& Ramsköld, L. (1996). The "Encrinurus" variolaris plexus (Trilobita, Silurian): Relationships of Llandovery species. Geobios, 29, 209-233. https://doi.org/10.1016/S0016-6995(96)80045-3

Feist, R., \& Lerosey-Aubril, R. (2008). Assessing the hypothesis of a third tagma in scutelluid trilobites: Arguments from ontogenetic, functional, and evolutionary perspectives. In R. Rábano, R. Gozalo, \& D. Garda-Bellido (Eds.), Advances in trilobite research (pp. 127-133). Madrid, Spain: Instituto Geológico y Minero de España.

Fortey, R. A., \& Owens, R. M. (1999). Feeding habits in trilobites. Palaeontology, 42, 429-465. https://doi.org/10.1111/1475-4983.00080

Hamada, T. (1959). The Goltlandian [sic] stratigraphy of the outer zone of Japan. Journal of the Geological Society of Japan, 65, 688-700. https:// doi.org/10.5575/geosoc.65.688

Harashinai, M. (1981). Discovery of Silurian conodonts in the vicinity of Gyoninzawa, Hikoroichi-machi, Ofunato City, Northeast Japan. Journal of the Geological Society of Japan, 87, 841-843. https://doi.org/10. 5575 /geosoc.87.841

Hisada, K., Arai, S., \& Negoro, A. (1994). Devonian serpentinite protrusion confirmed by detrital chromian spinels in outer zone of SW Japan. In Proceedings of the International Symposium on Stratigraphic Correlation of Southeast Asia. Department of Mineral Resources: Bangkok, Thailand.

Holloway, D. J. (1994). Early Silurian trilobites from the Broken River area, North Queensland. Memoirs of the Museum of Victoria, 54, 243-269. https://doi.org/10.24199/j.mmv.1994.54.12

Holloway, D. J., \& Lane, P. D. (1998). Effaced styginid trilobites from the Silurian of New South Wales. Palaeontology, 41, 853-896. https://doi. org/10.1111/j.1475-4983.2012.01132.x

Holloway, D. J., \& Lane, P. D. (2012). Scutelluid trilobites from the Silurian of New South Wales. Palaeontology, 55, 413-490. https://doi.org/10. 1111/j.1475-4983.2012.01132.x

Holloway, D. J., \& Lane, P. D. (2016). Trilobites of the suborder Illaenina from the Silurian of North Queensland, Australia. Journal of Paleontology, 90, 433-471. https://doi.org/10.1017/jpa.2016.29

Hughes, H. E., \& Thomas, A. T. (2011). Trilobite associations, taphonomy, lithofacies and environments of the Silurian reefs of North Greenland. Palaeogeography, Palaeoclimatology, Palaeoecology, 302, 142-155. https://doi.org/10.1016/j.palaeo.2010.12.009

Kaneko, A. (1990). A new trilobite genus Rhinophacops. Transactions and Proceedings of the Palaeontological Society of Japan, New Series, 157, 360-365. doi:10.14825/prpsj1951.1990.157_360

Kaneko, A. (2007). Nakazato trilobite Fauna (early to middle Devonian) (pp. 231-250). Tokyo, Japan: Jubilee Publication in Commemoration of Professor Tadao Kamei's 80th birthday, Commemorative Association of Professor Kamei Tadao's 80th birthday (in Japanese with English abstract).

Kato, M., Minato, M., Niikawa, I., Kawamura, M., Nakai, H., \& Haga, S. (1980). Silurian and Devonian corals of Japan. Acta Palaeontologica Polonica, 25, 557-566.

Kido, E., \& Sugiyama, T. (2007). Re-examination of the stratigraphy of the Silurian-Devonian and Carboniferous strata in the Gionyama area, 
Gokase-cho, Miyazaki prefecture. Proceedings, Nishinihon Branch, Geological Society of Japan, 153, 1-17.

Kido, E., \& Sugiyama, T. (2011). Silurian rugose corals from the Kurosegawa terrane, Southwest Japan, and their paleobiogeographic implications. Bulletin of Geosciences, 86(1), 49-61. https://doi.org/10.3140/ bull.geosci.1213

Kobayashi, T. (1988a). The Devonian trilobites from the Fukuji and other formations in Japan. Proceedings of the Japan Academy Series B-Physical and Biological Sciences, 64, 103-105. https://doi.org/10.2183/pjab. 64.103

Kobayashi, T. (1988b). New trilobites of the Devonian Fukuji fauna. Proceedings of the Japan Academy Series B-Physical and Biological Sciences, 64, 106-108. https://doi.org/10.2183/pjab.64.106

Kobayashi, T. (1988c). The Silurian trilobites in Japan. Proceedings of the Japan Academy, Series B-Physical and Biological Sciences, 64(1), 5-8. https://doi.org/10.2183/pjab.64.5

Kobayashi, T., \& Hamada, T. (1974). Silurian trilobites of Japan in comparison with Asian, Pacific and other faunas. Special Papers of the Palaeontological Society of Japan, 18, 1-155, 12 pls.

Kobayashi, T., \& Hamada, T. (1976). New Silurian trilobite from Ofunato, North Japan. Proceedings of the Japan Academy, 52, 367-370.

Kobayashi, T., \& Hamada, T. (1977). Devonian trilobites of Japan: in comparison with Asian, Pacific and other faunas. Special Papers of the Palaeontological Society of Japan, 20, 1-202, 13 pls.

Kobayashi, T., \& Hamada, T. (1985). Studies on Japanese trilobites and associated fossils. 41. On the Silurian trilobites and cephalopods of Mt. Yokokura, Shikoku, Japan. Proceedings of the Japan Academy Series B-Physical and Biological Sciences, 61, 345-347. https://doi.org/10. 2183/pjab.61.345

Kobayashi, T., \& Hamada, T. (1986). The second addition to the Silurian trilobite fauna of Yokokura-yama, Shikoku, Japan. Transactions and Proceedings of the Palaeontological Society of Japan, 143, 447-462.

Kobayashi, T., \& Hamada, T. (1987). On the Silurian trilobite faunule of Hitoegane near Fukuji in the Hida plateau, Japan. Transactions and Proceedings of the Palaeontological Society of Japan, 147, 131-145.

Kurihara, T. (2003a). Early Devonian Palaeoscenidiidae (Radiolaria) from the "Yoshiki formation" in the Fukuji area of the Hida Gaien terrane, Central Japan, and its biostratigraphic significance. Journal of the Geological Society of Japan, 109, 635-647. https://doi.org/10.5575/ geosoc.109.635

Kurihara, T. (2003b). Stratigraphy and geologic age of the middle Paleozoic strata in the Kuzuryu Lake-upper Ise River area of the Hida Gaien terrane, Central Japan. Journal of the Geological Society of Japan, 109, 425-441. https://doi.org/10.5575/geosoc.109.425

Kurihara, T. (2004). Silurian and Devonian radiolarian biostratigraphy of the Hida Gaien belt, Central Japan. Journal of the Geological Society of Japan, 110(10), 620-639. https://doi.org/10.5575/geosoc.110.620

Kurihara, T. (2007). Uppermost Silurian to lower Devonian radiolarians from the Hitoegane area of the Hida Gaien terrane, Central Japan. Micropaleontology, 53(3), 221-238. https://doi.org/10.2113/ gsmicropal.53.3.221

Kurihara, T. (2009). Late Silurian radiolarians from the Horagatake formation of the Kurosegawa terrane in the Tomochi area, Central Kyushu, Southwest Japan. News of Osaka Micropaleontologists, Special Volume, 14, 571-576.

Kurihara, T., Sato, Y., \& Tazawa, J. (2005). Early Devonian radiolarians from the Ohno formation in the Hikoroichi area of the South Kitakami Belt. Northeast Japan. Journal of the Geological Society of Japan, 111, 187-190. https://doi.org/10.5575/geosoc.111.187

Kuwano, Y. (1976). Finding of Silurian conodont assemblages from the Kurosegawa tectonic zone in Shikoku, Japan. Memoirs of the National Science Museum, 9, 17-22.

Kuwano, Y. (1980). Silurian conodonts from Yokokura-yama, Shikoku, Japan. Abhandlungen der Geologische Bundesanstalt in Wien, 35, 201.

Kuwano, Y. (1987). Early Devonian conodonts and ostracodes from Central Japan. Bulletin of the National Science Museum, Tokyo, Series C, 13, 77-105.

Lane, P. D., \& Thomas, A. T. (1980). A replacement name for Rhax lane and Thomas, 1978 (Trilobita) non Hermann, 1804. Geological Magazine, 117, 191.
Manchuk, N., Kurihara, T., Tsukada, K., Kochi, Y., Obara, H., Fujimoto, T., ... Yamamoto, K. (2013). U-Pb zircon age from the radiolarian-bearing Hitoegane Formation in the Hida Gaien Belt, Japan. Island Arc, 22, 494-507. https://doi.org/10.1111/iar.12044

Männik, P., Maekawa, T., Tanaka, G., Komatsu, T., Siveter, D. J., Williams, M., ... Vandenbroucke, T. R. A. (2018). The Ordovician and Silurian conodonts of Japan: Their biostratigraphical, paleoecological and paleobiogeographical significance. Island Arc. https://doi.org/10. 1111/iar.12269

Metcalfe, I. (2006). Palaeozoic and Mesozoic tectonic evolution and palaeogeography of east Asian crustal fragments: The Korean peninsula in context. Gondwana Research, 9, 24-46. https://doi.org/10. 1016/j.gr.2005.04.002

Niko, S. (2004). Late Silurian Favositida (Coelenterata: Tabulata) from the Hitoegane Formation, Gifu prefecture. Bulletin of the National Museum of Nature and Science, Series C, 30, 21-46.

Niko, S., \& Senzai, Y. (2010). Stratigraphy of the Devonian Kamianama Formation in the Kuzuryu Lake-Ise River area, Fukui prefecture and its favositid coral fauna. Bulletin of the National Science Museum, Tokyo Series C, 36, 31-59.

Ohno, T., Okazaki, Y., \& Hirano, K. (1977). Discovery of a trilobite at Izumi Village, Fukui prefecture. Chigaku Kenkyu, 28, 185-191.

Pan, H.-Z., \& Cook, A. G. (2003). Early Devonian gastropods from Zhusileng-haierhan region, Western Inner Mongolia, China. Journal of Paleontology, 77(1), 31-43. https://doi.org/10.1017/ s0022336000043390

Ramsköld, L. (1986). Silurian encrinurid trilobites from Gotland and Dalarna, Sweden. Palaeontology, 29, 527-575.

Saito, Y. (1992). Reading geologic history of Japanese Islands. Tokyo, Japan: Iwanamishoten.

Selwood, E. B. (1966). Thysanopeltidae (Trilobita) from the British Devonian. Bulletin of the British Museum (Natural History) Geology, 13, 117-190.

Sherwin, L., \& Meakin, S. (2010). The early Devonian trilobite 'Craspedarges' from the Winduck group, Western New South Wales. Proceedings of the Linnean Society of New South Wales, 131, 111-118.

Siveter, D. J., Tanaka, G., Williams, M., \& Männik, P. (2018). Japan's earliest ostracods. Island Arc. Advance online publication. https://doi.org/10. 1111/iar.12284

Speyer, S. E., \& Chatterton, B. D. E. (1989). Trilobite larvae and larval ecology. Historical Biology, 3, 27-60. https://doi.org/10.1080/089129 68909386512

Steeman, T., Vandenbroucke, T. R., Williams, M., Verniers, J., Perrier, V., Siveter, D. J., ... Emsbo, P. (2016). Chitinozoan biostratigraphy of the Silurian Wenlock-Ludlow boundary succession of the Long Mountain, Powys, Wales. Geological Magazine, 153(1), 95-109. https://doi. org/10.1017/s0016756815000266

Stocker, C., Tanaka, G., Siveter, D. J., Lane, P., Tsutsumi, Y., Komatsu, T., ... Williams, M. (2018). Biogeographical and Biostratigraphical significance of a new middle Devonian Phacopid trilobite from the Naidaijin Formation, Kurosegawa terrane, Kyushu, Southwest Japan. Paleontological Research, 22(1), 75-90. https://doi.org/10.2517/2017pr011

Stocker, C. P., Siveter, D. J., Lane, P. D., Williams, M., Oji, T., Tanaka, G., ... Vandenbroucke, T. R. A. (2018). The Silurian and Devonian proetid and aulacopleurid trilobites of Japan. Fossils and Strata.

Strusz, D. L. (1980). The Encrinuridae and related families, with a description of Silurian species from southeastern Australia. Palaeontographica Abteilung A, 168, 1-68.

Sugiyama, T. (1940). Stratigraphical and palaeontological studies of the Gotlandian deposits of the Kitakami Mountainland. The Science Reports of the Tohoku Imperial University, Series, 2(21), 81-146.

Tazawa, J. (1993). Pre-Neogene tectonics of the Japanese Islands from the viewpoint of palaeobiogeography. Journal of the Geological Society of Japan, 99, 525-543. https://doi.org/10.5575/geosoc.99.525

Tazawa, J. (2000). Permian brachiopod faunas and pre-Neogene tectonics in the inner side of Southwest Japan. Monograph of the Association for Geological Collaboration in Japan (Chidanken Senpo), 49, 5-22.

Tazawa, J. (2001). Middle Permian brachiopod faunas of Japan and south Primorye, Far East Russia: Their palaeobiogeographic and tectonic implications. Geosciences Journal, 5, 19-26. https://doi.org/10.5575/ geosoc.98.483 
Tazawa, J. (2002). Late Paleozoic brachiopod faunas of the South Kitakami Belt, Northeast Japan, and their paleobiogeographic and tectonic implications. Island Arc, 11, 287-301. https://doi.org/10.1046/j.14401738.2002.00369.x

Tazawa, J. (2004). Palaeozoic and Mesozoic tectonics of the Hida Gaien Belt, Central Japan. Journal of the Geological Society of Japan, 110, 567-579. https://doi.org/10.5575/geosoc.110.567

Thomas, A. T. (1979). Trilobite associations in the British Wenlock. In A. L. Harris, C. H. Holland, \& B. E. Leake (Eds.), The Caledonides of the British Isles - reviewed (pp. 447-451). London, England: Geological Society of London.

Tsukada, K., \& Koike, T. (1997). Ordovician conodonts from the Hitoegane area, Kamitakara village, Gifu prefecture. Journal of the Geological Society of Japan, 103, 171-174. https://doi.org/10.5575/geosoc. 103.171

Umeda, M. (1998a). Early to Middle Devonian Ceratoikiscidae (Radiolaria) from the Yokokurayama Group in the Kurosegawa Terrane, Southwest Japan. Paleontological Research, 2, 96-107.

Umeda, M. (1998b). Upper Silurian-middle Devonian radiolarian zones of the Yokokurayama and Konomori areas in the Kurosegawa Belt, Southwest Japan. Island Arc, 7, 637-646. https://doi.org/10.1046/j. 1440-1738.1998.00215.x

Vandenbroucke, T. R. A., Hints, O., Williams, M., Wallis, S., Velleman, J., Kurihara, T., ... de Backer, T. (2018). Palynomorphs (chitinozoans and scolecodonts) from the Silurian and Devonian of Japan. Manuscript submitted for publication.

Wang, Y., Boucot, A. J., Rong, J., \& Yang, X. (1987). Community paleoecologic tool: The Chinese Ashgillian-Eifelian (latest Ordovician through early middle Devonian) as an example. Special Paper of the Geological Society of America, 1-211.

Whittington, H. B. (1999). Siluro-Devonian Scutelluinae (Trilobita) from the Czech Republic: Morphology and classification. Journal of Paleontology, 73, 414.

Williams, M., Wallis, S., Oji, T., \& Lane, P. D. (2014). Ambiguous biogeographical patterns mask a more complete understanding of the Ordovician to Devonian evolution of Japan. Island Arc, 23, 76-101. https:// doi.org/10.1111/iar.12067

Yoshida, K., \& Machiyama, H. (2004). Provenance of Permian sandstones, South Kitakami terrane, Northeast Japan: Implications for Permian arc evolution. Sedimentary Geology, 166, 185-207. https://doi.org/10. 1016/j.sedgeo.2003.12.005

Zalasiewicz, J., Taylor, L., Rushton, A., Loydell, D., Rickards, R., \& Williams, M. (2009). Graptolites in British stratigraphy. Geological Magazine, 146, 785-850. https://doi.org/10.1017/s0016756809990434

Zhang, W. (1983). On the subfamily Coronocephalinae (Trilobita). Palaeontologica Cathayana, 1, 195-257.

Zhou, Z., \& Campbell, K. S. W. (1990). Devonian phacopacean trilobites from the Zhusilenghaierhan region, Ejin Qi, Western Inner Mongolia, China. Palaeontographica Abteilung A, 214, 57-77.

How to cite this article: Stocker CP, Siveter DJ, Lane PD, et al. The paleobiogeographical significance of the Silurian and Devonian trilobites of Japan. Island Arc. 2019;28:e12287. https://doi.org/10.1111/iar.12287 